\section{Nocturnal elemental diet for retarded growth in a patient with cystic fibrosis}

The combination of chronic pulmonary sepsis and pancreatic insufficiency in children with cystic fibrosis may lead to malnutrition. Indeed, most have a wasted appearance and retarded growth. ${ }^{1}$ One aim in treatment has therefore been to improve their nutrition. Several special diets, including intravenous feeding, have been tried. ${ }^{2}$ The introduction in 1960 of chemically defined diets provided a further possibility for nutritional support. ${ }^{3} \mathrm{We}$ describe our experience of the long-term use of continuous nocturnal infusion of elemental diet in a patient with cystic fibrosis.

\section{Case report}

A girl was diagnosed as having cystic fibrosis at the age of 2 years when she presented with steatorrhoea, rectal prolapse, and failure to thrive. Sweat sodium was $87 \mathrm{mmol}(\mathrm{mEq}) / 1$ and chloride $86 \mathrm{mmol}(\mathrm{mEq}) / 1$. Treatment was started with pancreatic supplements, vitamins, prophylactic chest physiotherapy, and oral antibiotics. On this treatment she remained asymptomatic until aged 10, although her growth curves lay on the third percentile for height and weight. From this time until her referral to us for nutritional treatment she had had no further increase in height or weight despite the addition of Caloreen $(100 \mathrm{~g} /$ day $)$ and medium-chain triglyceride oil $(10 \mathrm{ml} /$ day) to her diet. On referral at age 13 years she was of small stature $(131 \mathrm{~cm})$, weighed $20.4 \mathrm{~kg}$, and was obviously malnourished.

During a brief period in hospital she was instructed how to pass a size $8 \mathrm{~F}$ nasogastric tube. This was done in the evening immediately before going to bed, and an elemental diet (Vivonex HN, Eaton Laboratories) was infused continuously over the next 10 hours to provide $2.5 \mathrm{MJ}(600 \mathrm{kcal})$ and $4 \mathrm{~g}$ nitrogen in $600 \mathrm{ml}$ of water. A controlled infusion pump (Tekman T92) was used to avoid the possible danger of rapid gastric filling and inhalation of diet. After removal of the tube in the morning the patient ate a normal breakfast and attended school. This regimen was continued for eight months, stopped for six months, and then recontinued for a further two months. Haemoglobin $(12.4 \mathrm{~g} / \mathrm{dl})$ and serum albumin $(45 \mathrm{~g} / \mathrm{l})$ concentrations remained steady throughout. The figure shows the results of serial measurements of body weight and total body potassium (TBK) using a whole body counter. There had been no change in weight for the previous three years. During the first six months of nutritional support, however, body weight and TBK increased by $12 \%$. There was a small fall in weight and TBK when nutritional support was stopped but both rose to $20 \%$ of their prestudy values when nocturnal feeding was reintroduced. There was an overall increase in height of $2.5 \mathrm{~cm}$ during the study period.

\section{Comment}

Our patient tolerated the long-term nocturnal elemental diet well, and it enabled her to continue normal everyday activity and eat normal meals. Like Andrassy et $a{ }^{4}{ }^{4}$ who gave continuous elemental diet by catheter to children with a large variety of illnesses, we found the method easy to institute and free from side effects. Clearly, we cannot say from this single study whether such nutritional support affects the progress or outcome of the disease. Studies using predigested diets but not administered continuously have shown that nutritional state in cystic fibrosis may be improved but no definite effect on the mortality rate or morbidity of the disease. ${ }^{5}$

In our study the periods of nutritional support coincided with periods of increased body weight and total body potassium, indicating that the lean body mass was increased. These changes were associated with the subjective finding of a general increase in the patient's vitality during treatment. We think that these results show a need for further studies of this form of home treatment in children with cystic fibrosis.

1 Weihoten, D M, and Pringle, D J, fournal of the American Dietetic Association, 1969, 54, 206.

2 Shwachman, H, Pediatric Clinics of North America, 1975, 22, 787.

${ }^{3}$ Couch, R, et al, Federation Proceedings, 1960, 19, 13.

4 Andrassy, R J, et al, Surgery, 1977, 82, 205.

5 Berry, H K, et al, American fournal of Diseases of Children, 1975, 129, 165.

(Accepted 7 November 1978)

University Department of Surgery and Department of Gastroenterology, The General Infirmary, Leeds LS1 3EX

J A BRADLEY, MB, research fellow

A T R AXON, MD, MRCP, consultant gastroenterologist

G L HILL, CHM, FRCS, senior lecturer in surgery

\section{Large epidermal cyst of breast simulating malignant growth}

Sebaceous cysts are not uncommon in the skin over the breast, ${ }^{1}$ but true epidermal cysts are rare. We report a case of an unusually large epidermal cyst of the breast which clinically resembled a malignant growth.

\section{Case report}

A 61-year-old widow was admitted to hospital complaining of a swelling in the right breast of one year's duration. The swelling had increased rapidly over the last two months and was slightly painful. She was of average build and nutrition with moderate anaemia. She had three children alive, the

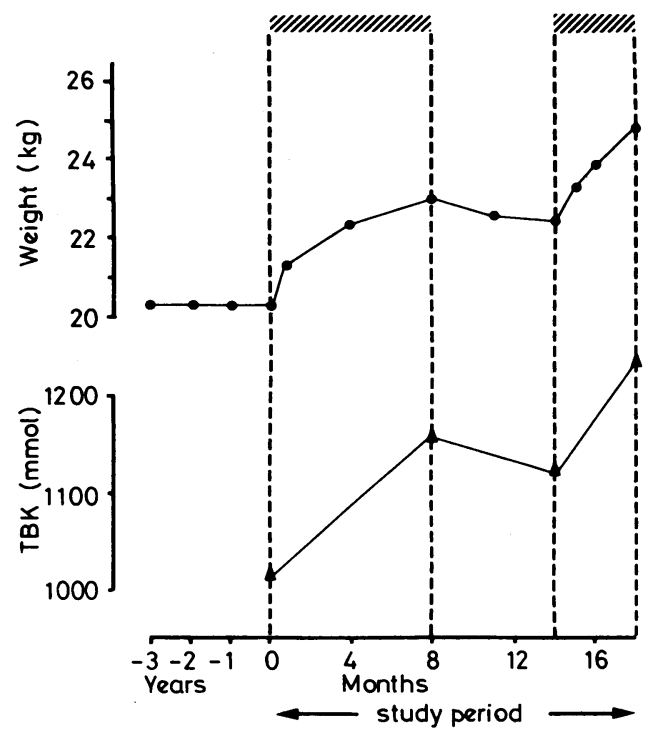

Changes in body weight and total body potassium over the study period in a patient with cystic fibrosis. youngest aged 20. The menopause had occurred 15 years previously. Her right breast was tense because of a firm mass of about $8 \mathrm{~cm} \times 5 \mathrm{~cm}$, globular with a smooth margin, occupying almost the entire breast. The skin was free. No axillary or supraclavicular lymph nodes were palpable. The result of an $x$-ray examination of the chest was normal. Routine investigations did not 
show any abnormality. Carcinoma of the breast was diagnosed and a mammogram was performed. This showed a large circular mass with increased density, homogeneous and with well-demarcated borders, compressing the surrounding breast tissue. There was no thickening of the skin. Aspiration produced from a tense cyst about $70 \mathrm{ml}$ of chocolate-coloured fluid containing flakes of tissue. About $50 \mathrm{ml}$ of air was injected and a contrast mammogram was taken with the patient erect. ${ }^{2}$ It showed a fluid level and confirmed the diagnosis of a cyst (figure). This was removed intact leaving a rim of atrophied breast tissue. Macroscopically the cyst was very tense, globular, and of about $10 \mathrm{~cm}$ in diameter. The outer wall was shaggy. It was multiloculated and contained chocolate-coloured fluid with whitish tissue debris. Histologically it was a typical epidermal cyst lined with stratified squamous epithelium and the cavity contained laminated layers of keratin.

\section{Comment}

Epidermal cysts are usually located on the exposed surfaces of the body. They are filled with keratin,which is often arranged in laminated layers. They commonly result from trauma (including insect bites) or inflammatory down growth with separation and eventual isolation and encystment of a fragment of epidermis. Our case is unusual in three respects. (1) Though small sebaceous cysts are not uncommon in the skin over breast, reports of large epidermal cysts are rare. (2) Multiloculated cysts are uncommon. (3) The cyst's tenseness and firmness gave an appearance of malignancy, which routine mammography seemed to confirm. Luckily, aspiration disclosed the cystic nature of the tumour and air-contrast mammography clinched the diagnosis. The case also illustrates the value of air-contrast mammography in any doubtful cystic lesion of the breast.

We thank Dr A L Goswami, Chief Medical Officer, S E Railway, India, for permission to report the case, and $\mathrm{Mr} \mathrm{P} \mathrm{N}$ Biswal for secretarial assistance.

${ }^{1}$ Haagen Sen, C D, Diseases of the Breasts, 2nd edn, p 335. Philadelphia, W B Saunders, 1971

${ }^{2}$ Hebert, G, and Quimet, Oliva D, American fournal of Roentgenology, 1972, 115, 801 .

(Accepted 15 November 1978)

South Eastern Railway Hospital, Calcutta - 700 043, India

P K CHATTERJEE, MD, DCP, senior pathologist

$S$ N ROY, MD, DMRD, senior radiologist

\section{Comparison of effects of propranolol and metoprolol on airways obstruction in chronic bronchitis}

Beta-adrenergic blockade is an established treatment for hypertension and angina pectoris; coexisting chronic obstructive bronchitis is common in such patients. Propranolol ${ }^{1}$ and metoprolol ${ }^{23}$ have been assessed in patients with bronchial asthma but there is little information on the effect of metoprolol on the airways of patients with chronic bronchitis. ${ }^{4}$ I report a study on the effect of intravenous propranolol and metoprolol on airways obstruction and the response to inhaled isoprenaline in such patients.

\section{Patients, methods, and results}

Ten patients with a mean age of 63 years were studied. All were cigarette smokers with symptoms of longstanding chronic bronchitis, a mean forced expiratory volume in one second $\left(\mathrm{FEV}_{1}\right)$ of less than $70 \%$ predicted value, negative skin tests, and without blood eosinophilia. They attended at the same time of day on three occasions, having had no bronchodilator drugs for 10 hours. After 20 minutes' rest $\mathrm{FEV}_{1}$, forced vital capacity (FVC), specific airways conductance (SGaw), and pulse were measured twice to ensure a stable baseline. Propranolol $(0.06 \mathrm{mg} / \mathrm{kg}$, mean $3.8 \mathrm{mg})$, metoprolol $(0.12 \mathrm{mg} / \mathrm{kg}$, mean $7.6 \mathrm{mg})$, and $0.9 \%$ saline were given by slow intravenous injection in a double-blind random order. The measurements were repeated $15,30,45$, and 60 minutes after the drug. Thereafter $0.16 \mathrm{mg}$ of aerosol isoprenaline sulphate was administered and the measurements repeated 10 minutes later.
The results (see table) were analysed using a paired sample Wilcoxon test. After propranolol there was a significant fall in $\mathrm{FEV}_{1}$ and FVC throughout the hour of study. Metoprolol produced no significant change in $\mathrm{FEV}_{1}$ but a fall in FVC. On comparing the two drugs the fall in FEV 1 and FVC at 15 minutes after propranolol was significantly greater than after metoprolol $(P<0.05)$. Both drugs produced a significant fall in pulse rate $(P<0.002)$. $\mathrm{FEV}_{1}$ improved after aerosol isoprenaline in each group $(\mathrm{P}<0.01)$. With propranolol, however, it did not reach the pretreatment measurement. The final measurements of $\mathrm{FEV}_{1}$ and $\mathrm{FVC}$ with propranolol and isoprenaline were significantly lower than with placebo and isoprenaline $(\mathbf{P}<0.01)$ or with metoprolol and isoprenaline $(P<0.05)$. Mean $S G a w$ improved after isoprenaline in each group $(P<0.01)$, but the improvement was significantly greater with metoprolol than it was with propranolol $(\mathrm{P}<0.02)$.

Mean FEV $V_{1}$ and FVC (litres), SGaw $\left(\mathrm{s}^{-1} \mathrm{kPa}^{-1}\right)$, and pulse (beats/min) before treatment and after aerosol isoprenaline, and the changes after intravenous drugs

\begin{tabular}{|c|c|c|c|c|c|c|}
\hline \multirow{2}{*}{ Treatment } & \multirow{2}{*}{$\begin{array}{l}\text { Mean values } \\
\text { before } \\
\text { intravenous } \\
\text { drugs }\end{array}$} & \multicolumn{4}{|c|}{$\begin{array}{c}\text { Mean changes after intravenous } \\
\text { drugs at: }\end{array}$} & \multirow{2}{*}{$\begin{array}{c}\text { Mean values } \\
\text { after } \\
\text { aerosol } \\
\text { isoprenaline }\end{array}$} \\
\hline & & +15 & +30 & +45 & $\begin{array}{l}+60 \\
\min \end{array}$ & \\
\hline Placebo & $\left\{\begin{array}{l}F_{1} 1 \cdot 34 \\
\text { FVC } 2 \cdot 79 \\
\text { SGaw } 0.50 \\
\text { pulse } 77\end{array}\right.$ & $\begin{array}{l}-0 \cdot 04 \\
-0 \cdot 02 \\
0 \\
-3\end{array}$ & $\begin{array}{l}\quad 0 \\
+0 \cdot 05 \\
+0 \cdot 02 \\
-4\end{array}$ & $\begin{array}{l}+0.01 \\
+0.12 \\
+0.03 \\
-5\end{array}$ & $\begin{array}{l}-0.02 \\
+0.07 \\
+0.03 \\
-5\end{array}$ & $\begin{array}{l}1 \cdot 47 \\
3 \cdot 10 \\
0 \cdot 70 \\
73\end{array}$ \\
\hline Propranolol & $\left\{\begin{array}{l}\mathrm{FEV}_{1} 1.33 \\
\text { FVC } 2 \cdot 77 \\
\text { SGaw } 0.45 \\
\text { pulse } 80\end{array}\right.$ & $\begin{array}{l}-0.20^{*} \\
-0.37 \ddagger \\
-0.07 \\
-14\end{array}$ & $\begin{array}{l}-0.14 \dagger \\
-0.28_{+}^{+} \\
-0.04 \\
-17\end{array}$ & $\begin{array}{l}-0.15^{*} \\
-0.20_{+}^{+} \\
+0.07 \\
-16\end{array}$ & $\begin{array}{l}-0.12 \dagger \\
-0.15^{*} \\
-0.01 \\
-17\end{array}$ & $\begin{array}{l}1 \cdot 30 \\
2 \cdot 79 \\
0.53 \\
64\end{array}$ \\
\hline Metoprolol & $\left\{\begin{array}{l}\text { FEV }_{1} 1.29 \\
\text { FVC } 2 \cdot 75 \\
\text { SGaw } 0.45 \\
\text { pulse } 79\end{array}\right.$ & $\begin{array}{l}-0.07 \\
-0.14+ \\
-0.03 \\
-16\end{array}$ & $\begin{array}{l}-0.07 \\
-0.22+ \\
-0.01 \\
-16\end{array}$ & $\begin{array}{l}-0.06 \\
-0.18 \pm \\
+0.05 \\
-18\end{array}$ & $\begin{array}{c}-0.03 \\
-0.12 \\
0 \\
-16\end{array}$ & $\begin{array}{l}1.43 \\
3.00 \\
0.69 \\
63\end{array}$ \\
\hline
\end{tabular}

On comparison with placebo: ${ }^{*} \mathrm{P}<0.02 .+\mathrm{P}<0.05 . \pm \mathrm{P}<0.01$

Conversion: SI to traditional units-SGaw: $\mathrm{s}^{-1} \mathrm{kPa}^{-1} \approx \mathrm{s}^{-1} \mathrm{cmH}_{2} \mathrm{O}^{-1} \times 10$.

\section{Comment}

Sympathetic activity is increased in patients with chronic bronchitis; consequently there is a risk of deterioration in symptoms and increased airways obstruction when beta-blockers are used. ${ }^{5}$ Two patients had increased dyspnoea after intravenous propranolol. There was no evidence of cardiac failure and no additional treatment was required. Both patients had initially poor ventilatory function and there was no clinical deterioration on the day they received intravenous metoprolol. Propranolol acts on beta ${ }_{2}-$ receptors in bronchial smooth muscle, producing bronchoconstriction, while metoprolol produces no significant change. Thus in patients with chronic bronchitis metoprolol is less likely to produce deterioration in ventilatory function and clinical symptoms. Nevertheless, since beta-blockers are given by mouth over long periods and at various doses further study of metoprolol under such conditions would be appropriate. It is impossible to predict the effect of beta-blockers on the airways obstruction of individual patients, and whenever possible ventilatory function should be monitored during the initial phase of treatment. I took care in this study to exclude patients with bronchial asthma. A previous report, ${ }^{3}$ however, showed that the response to metoprolol is unpredictable in such patients and therefore should be used with caution.

I conclude that metoprolol is a safer drug than propranolol when beta-blockade is required in patients with moderately severe chronic obstructive bronchitis. This is of clinical importance in view of the increasing use of these drugs for angina pectoris and hypertension, diseases commonly associated with chronic bronchitis.

I thank Dr R N Johnston for advice and allowing me to study patients under his care; Dr I M Slessor, medical director of Astra Chemicals, for supplies of metoprolol; and S J Pocock for statistical advice and analysis.

${ }^{1}$ McNeill, R S, Lancet, 1964, 2, 1101.

2 Johnston, G, Svedmyr, N, and Thiringer, G, European fournal of Clinical Pharmacology, 1975, 8, 175.

${ }^{3}$ Skinner, C, British Medical fournal, 1976, 1, 504.

4 Tivenius, L, Scandinavian fournal of Respiratory Disease, 1976, 57, 190.

${ }^{5}$ Astin, T W, Clinical Science, 1972, 43, 881.

(Accepted 15 November 1978)

Pulmonary Function Laboratory, Department of Clinical Measurement, Ninewells Hospital, Dundee DD1 9SY

D J M SINCLAIR, MB, MRCP, senior registrar in respiratory medicine 